Maciej Zakrzewski

Uniwersytet Papieski Jana Pawła II w Krakowie

\title{
Stanisław Swianiewicz i jego wspomnienie o Studnickim [nota redakcyjna]
}

\section{Niemiecki numer "Kultury"}

28 czerwca 1982 r. redaktor paryskiej „Kultury" Jerzy Giedroyc pisał do Stanisława Swianiewicza:

mam bowiem wielką prośbę. Chcę wydać na jesieni specjalny numer K[ultury] w języku niemieckim. Bardzo mnie do tego zachęciła obecna sytuacja, jak również b. pozytywny oddźwięk naszego apelu do Niemiec. Chcę więc prosić Pana o artykuł do tego n[ume]ru, jak również wszystkie sugestie co do tematów i autorów. J. J. Lipski, który jest w Londynie, obiecał mi opracowanie pokłosia namiętnej dyskusji, jaką wywołał jego artykuł Dwie ojczyzny. Bardzo to kładę Panu na sercu².

16 lipca Swianiewicz przychylnie odpowiedział na apel redaktora, pisząc: „jeżeli chodzi o artykuł do numeru niemieckiego, to mam w tej chwili określony koncept. Przyszło mi do głowy, że mógłbym spróbować napisać osobiste wspomnienie o Władysławie Studnickim"3. i ksenofobii Polaków, w: J. J. Lipski, Pisma polityczne. Wybór, Warszawa 2011, s.145173; w tomie zawarta jest również polska wersja tekstu napisanego do „Kultury", pt. List otwarty do polskich i niemieckich komentatorów mojej pracy Dwie ojczyny-dwa patriotyzmy (J. J. Lipski, Pisma polityczne..., op. cit., s.194-198).

2 Instytut Literacki Kultura, Kor Red Swianiewicz, List J. Giedorycia do S. Swianiewicza, 28 czerwca $1982 \mathrm{r}$.

3 ILK, Kor Red Swianiewicz, List S. Swianiewicza do J. Giedroycia, 16 lipca 1982 r. 
Wydanie numeru niemieckiego w tak szybkim tempie okazał się jednak założeniem nazbyt optymistycznym. Ostatecznie prace ruszyły około początku roku 1983. 24 lutego 1983 r. tekst Swianiewicza w języku polskim został wysłany do redakcji ${ }^{4}$. Tzw. numer niemiecki wyszedł jesienią $1984 \mathrm{r}^{5}$. Zawierał on artykuły polskich autorów, takich jak m.in.: Konstanty Jeleński, Adam Michnik, Zdzisław Najder, Jan Józef Lipski, Jerzy Stempowski, Czesław Miłosz, Gustaw Herling-Grudziński oraz wspominany Stanisław Swianiewicz. Zestaw znanych nazwisk silnie podkreślał chęć przedstawienia czytelnikowi niemieckojęzycznemu najwybitniejszych autorów mniej lub bardziej związanych z Instytutem Literackim. Prezentowane teksty nie tylko traktowały o zagadnieniu relacji polsko-niemieckich, ale też były swoistą promocją tego, czym jest „Kultura" w kręgu niemieckim. Stąd tom otwierał Konstanty Jeleński z artykułem Kultura - eine polnische Zeitschtift im Exil ${ }^{6}$, a w dziale eseje trzy teksty wybitnych autorów polskiej literatury nie tylko emigracyjnej (Miłosz, Herling-Grudziński, Stempowski). W dziale historycznym opublikowano dwa teksty: Witolda Pronobisa Josef Pilsudski und die Machtergreifung in Deutschland) oraz Erinnreungen an Wladyslaw Studnicki Swianiewicza7. Ponadto zamieszczono krótki wybór niemieckiej poezji romantycznej z okresu po upadku powstania listopadowego (Polenlieder deutscher Dichter der Romantik) ${ }^{8}$.

Konstrukcja bloku historycznego wyraźnie nawiązywała do najważniejszych wątków polsko-niemieckiego zbliżenia w historii porozbiorowej. Z jednej strony została przywołana dawna, wyraźnie propolska tradycja niemieckiego romantyzmu (zauważmy, że była to propolskość na poziomie społecznym, wyraźnie pasująca do odwilży we wzajemnym postrzeganiu w okresie po wprowadzeniu stanu wojennego w grudniu 1981 r.) , z drugiej zaś, dzięki Pronobisowi, Giedroye ukazał genezę paktu o nieagresji z 1934 r., (który wynikał z upadku koncepcji wojny prewencyjnej). Tom wieńczyło wspomnienie o najkonsekwentniejszym przedstawicielu orientacji proniemieckiej w Polsce - Władysławie Studnickim.

\footnotetext{
4 ILK Kor red Swianiewicz, List S. Swianiewicza do J. Giedroycia, 24 lutego 1982 r.

$5 \quad$ "Kultura", Herbst (1984).

$6 \quad$ "Kultura", op. cit., s. 3-17.

7 "Kultura", op. cit., s. 140-166.

8 "Kultura", op. cit., s. 124-139
} 
$\mathrm{Ku}$ orientacji proniemieckiej

Swianiewicz w swoim eseju połączył opis swoich osobistych doświadczeń ze Studnickim z analizą ważniejszych punktów jego teorii geopolitycznej. Co więcej, w tekście uwzględnił dwóch spadkobierców nie tyle doktryny, co samej "orientacji na Niemcy" Studnickiego: Stanisława Cata Mackiewicza i Adolfa Bocheńskiego. Obaj autorzy byli zbyt wielkimi intelektualnymi indywidualnościami, aby ograniczać się do roli biernych wyznawców.

Jednak ta charakterystyka Studnickiego, niejako „z lotu ptaka", rozpoczęła się w 1919 r., kiedy młody Swianiewicz spotkał w Wilnie całkiem rozpoznawalnego wówczas Studnickiego. W sierpniu 1919 r. poznał polityka o ugruntowanych poglądach, których katalizatorem był okres pierwszej wojny światowej. Warto pokrótce scharakteryzować właśnie okres kształtowania się fundamentów orientacji proniemieckiej Studnickiego.

W czasach swojej działalności socjalistycznej Studnickiego niewiele zajmowało zagadnienie niemieckie. Jako spadkobierca polskiej tradycji niepodległościowej głównego antagonisty na drodze Polaków do niepodległości upatrywał w Rosji. Już wtedy wykluczał możliwość odnowienia międzynarodowej koniunktury roku 1863 r., kiedy to powstanie styczniowe doprowadziło do ścisłego współdziałania Prus i Rosji (tzw. konwencja Alvenslebena). W okresie kiedy Studnicki "orbitował" w kierunku narodowej demokracji, zdecydowanie silniej akcentował, w duchu wszechpolskim, antagonizm względem Prus9. Dużą rolę w tej zmianie optyki odegrało porzucenie ideowej platformy socjalizmu. Wcześniej wyraźnie podkreślał wagę niemieckiego proletariatu i socjaldemokracji w paraliżu ewentualnych prób restytucji linii Bismarckowskiej.

Jeszcze do roku 1907 r. Studnicki, wskazując istnienie dwóch dróg do niepodległości: w oparciu o Rosję na zasadzie federacji bądź jako trzeci człon monarchii Habsburgów, wyraźnie skłaniał się do pierwszej opcji zmierzającej do budowy autonomii w ramach Królestwa, co miało być wstępem do dalszych działań ${ }^{10}$. Jednak w 1907 r. Studnicki wyraźnie odciął się od kierunku ugodowego wobec Rosji. To Rosja ponownie zyskała status naczelnego wroga sprawy Polskiej. Jak podkreślał Jan Sadkiewicz, "każde pomniejszenie granic zaboru rosyjskiego na rzecz austriackiego czy nickiego (do 1939 roku), Toruń 1998, s. 140-141. 
pruskiego uznawał [Studnicki] za korzystne dla sprawy polskiej, stąd postulował agresywną wobec Rosji politykę Austro-Węgier"11. W tym czasie nie była to jeszcze orientacja proniemiecka, ale zdecydowanie antyrosyjska. Antyrosyjskość determinowała strategiczny ogląd pozostałych elementów. Na przełomie 1908/1909, jak zauważył Gzella, państwo niemieckie stało się w opinii Studnickiego potencjalnym sojusznikiem ${ }^{12}$. Stąd Studnicki na przekór narodowym nastrojom protestował przeciwko rozdmuchiwaniu krakowskich obchodów bitwy pod Grunwaldem w 1910 r. ${ }^{13}$ Podkreślał, że rozpoczynanie akcji niepodległościowej od Prus w obecnej konstelacji jest nieporozumieniem, stąd symboliczne gesty bez praktycznego znaczenia nie miały racji bytu.

Kluczowa teoretyczna praca Studnickiego z tego okresu "Sprawa Polska" była frontalnym atakiem na orientację prorosyjską Dmowskiego $^{14}$. Studnicki podkreślał, że Austro-Węgry winny być punktem oparcia dla działań niepodległościowych Polaków, a włączenie ziem Królestwa Polskiego pod panowanie Habsburgów byłoby gwarantem równowagi europejskiej. Trzeba jednak zaznaczyć, iż całej przemianie orientacji na Niemcy towarzyszyła ciągła uwaga Studnickiego odnośnie polityki germanizacyjnej na terenie Prus ${ }^{15}$. Studnicki jednak zdecydowanie wybierał perspektywę geopolityczną jako fundament odzyskania niepodległości.

Katalizatorem dojrzałej opcji proniemieckiej Studnickiego był okres I wojny światowej. Pozostając poza NKN, działał samodzielnie. Obserwując z bliska zdolności organizacyjne wojska niemieckiego i blednące w jego świetle możliwości Habsburgów, zdecydowanie w tej "sile mobilizacji" dostrzegał szansę na dalsze kształtowanie oblicza regionu. Dodatkowo na odwrót od koncepcji trializmu wpłynęła jego wizyta na Węgrzech wiosną 1915 r., gdzie przekonał się w rozmowach z tamtejszymi politykami, iż włączenie Królestwa Polskiego jako trzeciego trzonu monarchii austrowęgierskiej nie cieszy się popularnością, a wręcz jest widziane negatywnie ${ }^{16}$.

11 J. Sadkiewicz, "Ci, którzy przekonać nie umieja". Idea porozumienia polsko-niemieckiego w publicystyce Władysława Studnickiego i wileńskiego "Słowa" (do 1939), Kraków 2012, s. 53.

12 J. Gzella, Zabory i sąsiedzi..., op. cit., s. 155.

13 W. Studnicki, W sprawie obchodu grunwaldzkiego, Kraków 1910.

14 W. Studnicki, Sprawa Polska, Poznań 1910.

15 J. Gzella, Zaborcy i sąsiedzi..., op. cit., s. 164.

16 Ibidem, s. 170. 
Po zajęciu przez Niemców Warszawy w 1915 r. dla Studnickiego sytuacja wydawała się klarowna. Coraz mocniej propagował idee budowy państwa polskiego złożonego z Galicji, ziem dawnego Królestwa Polskiego i tzw. ziem zabranych. W imię strategicznej współpracy porzucał idee włączenia ziem zaboru pruskiego do przyszłego bytu państwowego ${ }^{17}$. Z jednej strony Niemcy mieli zyskać osłonę od strony Rosji, Polacy oprócz własnego państwa otrzymywaliby silne geopolityczne oparcie dla swojej niepodległości.

Studnicki od samego początku sondował wśród niemieckich kół wojskowych szansę prowadzenia przez II Rzeszę działań w postulowanym przez niego kierunku. Dopiero jednak linia polityczna generała gubernatora Hansa von Beselera była realnym odzewem po stronie niemieckiej na gotowość współpracy ze strony Studnickiego ${ }^{18}$. Jak pisał Arkadiusz Stempin o postawie Beselera:

Jako wojskowy największą wagę przykładał do rozbudowy armii. Jeśli w trakcie zapasów z armią rosyjską w berlińskich gabinetach planowano doraźne pozyskanie polskiego żołnierza, to dopiero wskutek nacisku Beselera przyjęto tam program restytucji polskiej państwowości. Dlatego też po klęsce odezwy werbunkowej, która w politycznym Berlinie wywołała zniechęcenie do idei odbudowy państwa i wojska polskiego, Beseler forsował ją z nie mniejszym temperamentem. A armię polską, którą zamierzał wyszkolić według sprawdzonego niemieckiego wzoru, wyniósł do rangi głównego spoiwa, scalającego po wojnie Rzeszę i wskrzeszoną polską monarchię. Ponadto obydwa państwa widział, zgodnie z koncepcją Mitteleuropy Neumanna, złączone gęsta siecia powiązań gospodarczych i kulturowych. Przesłanek do wzmocnienia tych ostatnich Beseler doszukiwał się w istniejącej naturalnej kulturowej bliskości Polski i Niemiec, wyprowadzanej z faktu przynależności Polski do kręgu języka łacińskiego i zachodniego chrześcijaństwa. W tym kontekście tymczasową okupację ziem polskich podczas wojny traktował jako niepowtarzalną szansę na zainicjowanie op. cit., s. 169-171.

18 Zob. A. Stempin, Generał-pułkownik Hans Hartwig von Beseler - generalny gubernator warszawski w latach 1915-1918, "Dzieje Najnowsze" R. 43, z. 3 (2011), s. 21-34. 
procesu przeszczepienia niemieckiego modelu państwa na grunt polski, ze szkolnictwem i nauką włącznie. Warszawa miała stać się oknem wystawowym niemieckiego dorobku cywilizacyjnego. W tak paternalistycznie pojmowanej wizji modernizacji kraju nie było miejsca na większą korektę kursu uwzględniającą postulaty polskich ugrupowań niepodległościowych ${ }^{19}$.

Prawdopodobnie Studnicki był najbardziej szczerym i oddanym odbiorcą idei Beselera po stronie polskiej. Na skutek doświadczenia organizacyjnej i militarnej sprawności Niemiec, kontrastującej z nieudolnością Austriaków, przemodelował pierwotną, strategiczną proniemieckość na trwały projekt geopolityczny, który za zachodnią granicą Królestwa Polskiego określany był mianem Mitteleuropy ${ }^{20}$.

Studnicki założył w lipcu 1916 r. aktywistyczny Klub Państwowców Polskich ${ }^{21}$ pragnący pełnić rolę pomostu władzami okupacyjnymi a polskim społeczeństwem. Akt 5 listopada był momentem, który nie tylko w opinii Studnickiego, "dźwignął sprawę polską z poziomu pragnień autonomicznych do postulatu odrębności państwowej"22. Z obecnej perspektywy historycznej właściwie możemy docenić wagę tego wydarzenia i prawdziwość stwierdzenia Studnickiego. Dla Polaków rzeczywiście kończył się etap walki o autonomię w ramach jednego z państw zaborczych, a zaczynał się etap działań na rzecz własnego państwa. Każdy uczestnik wielkiej rozgrywki międzynarodowej po 5 listopada 1916 r. chcący podnieść sprawę polską nie mógł licytować niżej. Studnicki lojalnie wspierał politykę Beselera (poparł m.in. odezwę werbunkową z 9 listopada 1916 r.). Został członkiem Tymczasowej Rady Stanu, co podkreśla Gzella, w jej ramach prezentował opcję najbardziej ugodową względem Niemców, szybko popadał przez to w polityczną izolację ${ }^{23}$. Wielokrotnie też wzywał Niemców do szczerego i konsekwentnego wypełniania „ducha" aktu listopadowego.

19 A. Stempin, Generał-pułkownik..., op. cit., s. 24-25.

20 O koncepcji Mitteleuropy, zob. szerz. m.in. P. Eberhardt, Geneza niemieckiej koncepcji "Mitteleuropy", "Przegląd Geograficzny" t. 77 (2005), s. 463-483.

21 W zarządzie KPP zasiedli obok Studnickiego: Zygmunt Makowiecki, Stanisław Tarczyński, Zygmunt Kramsztyk, Janusz Suski, Antoni Humnicki, Ludwik Zawadzki i Wincenty Rzymowski.

22 Za J. Gzella, Zaborcy i sąsiedzi..., op. cit., s. 179.

23 Jak wspomina autor tylko jeden z wielu zgłaszanych przez niego wniosków na forum TRS zyskał poparcie reszty radców (J. Gzella, Zaborcy i sąsiedzi..., op. cit., S. 181). 
Kryzys przysięgowy był końcem współpracy polsko-niemieckiej w dużej skali. Studnicki został wykluczony przez TRS ze swojego składu. W czerwcu 1918 r. dzięki wsparciu administracji niemieckiej zasilił skład Rady Stanu, w której zasiadał do 7 października. Praktyczny wymiar koncepcji zanikał, jednak Studnicki pozostawał jej wierny. W tym czasie na łamach pisma "Naród i Państwo" rozbudowywał swoją koncepcję przebudowy Europy Środkowej pod patronatem Niemiec, która nie tylko opierałaby się na sojuszu politycznym, ale także na integracji gospodar$\mathrm{czej}^{24}$.

Prawdopodobnie po tzw. kryzysie przysięgowym w Polsce i w Niemczech było tylko dwóch równie osamotnionych polityków: Beseler i Studnicki. Stanisław Łoś w swoich wspomnieniach tak charakteryzował generała gubernatora: „Beseler był szczery. Nie wdaję się w roztrząsania, czy i ile było dobrej wiary w poczynaniach tych czynników niemieckich, które poparły zabiegi i zamiary Beselera - ale Beseler działał bona fide. Jeżeli nawet malował przed oczyma Polaków majaki ułudne, to sam pierwszy uległ własnemu złudzeniu"25.

Beseler zmarł w 1921 r., Studnicki przeżył go o ponad trzydzieści lat. Przez te kolejne dekady, zobrazowane już przez Swianiewicza, toczył niemal samotne boje o zbliżenie polsko-niemieckie. Swianiewicz znakomicie odmalował obraz tych donkiszotowskich zmagań, opisując swoje spotkania i myśl „sieroty po Mitteleuropie". W czasie istnienia II Rzeczpospolitej nie tylko był najbardziej konsekwentnym orędownikiem zbliżenia polskoniemieckiego, ale i patronem dla nielicznego, ale ważnego grona polskich konserwatywnych polityków proniemieckich. Niemal w przededniu wojny wydał proroczą książkę, której nakład skonfiskowano na wniosek MSZ. Tytuł książki brzmiał W obliczu nadchodzacej wojny światowej. To w niej Swianiewicz przewidział zdradę Zachodu i tragiczne jej skutki dla Polski. W czasie wojny apelował do Niemców o zaniechanie terroru, bezskutecznie. Był więźniem Pawiaka, po wojnie zmarł na emigracji.

\section{Giedroyc a Studnicki}

Poniżej prezentowany tekst został napisany w języku polskim, ukazał się jedynie w tłumaczeniu. Jego zamieszczony poniżej polski pierwowzór

24 J. Sadkiewicz, "Ci, którzy przekonać..., op. cit., s. 67.

25 S. Łoś, „Świat się w mych oczach dwukrotnie zawalił...". Wspomnienia dyplomaty, red. M. Marszał, S. Wójtowicz, Kraków-Warszawa 2017, s. 150. 
spoczywał dotychczas w Archiwum Instytutu Literackiego w Maison-Laffitte $^{26}$. Artykuł, jak wspomniano powyżej, jest tekstem szczególnym nie tylko ze względu na bohatera, ale także samego Jerzego Giedroycia. Sam Swianiewicz wymienia jako uczniów Studnickiego dwie postaci: Stanisława Mackiewicza i Adolfa Bocheńskiego. Nie należy zapominać, że Adolf Bocheński był naczelnym geopolitycznym publicystą przedwojennych pism redagowanych przez Giedroycia, tj. „Buntu Młodych" (od 1937 r. „Polityki"). Oba tytuły nigdy nie były czymś na kształt forum dyskusyjnego, starano się, oczywiście z różnym rezultatem w zakresie spójności, wypracowywać wspólną linię programową całego środowiska. Świadczy o tej tendencji choćby manifest „Polska idea imperialna" z 1938 r. W kształtowaniu linii programowej Giedroyc, nie piszący wprawdzie artykułów, odgrywał decydującą rolę. W zakresie polityki międzynarodowej przyjmowano zdecydowanie za punkt wyjścia hasło porozumienia z państwem niemieckim. „Bunt Młodych" i „Polityka" do wiosny 1939 obok wileńskiego „Słowa" były głównymi ośrodkami optującymi za strategicznym i wymierzonym przeciwko Sowietom zbliżeniem z III Rzeszą. Przywołana przez Swianiewicza praca Adolfa Bocheńskiego „Między Niemcami a Rosją" wydana była nakładem „Polityki" i zawierała szereg fragmentów zamieszczonych uprzednio w „Buncie". Współpracy z Niemcami nie traktowano jako projektu trwałego, jak to czynił Studnicki, jednak zdecydowanie dostrzegano w niej szanse na przebudowę, podług interesów Polski, układu politycznego Europy Środkowo-Wschodniej. Jak cała koncepcja Bocheńskiego, tak linia polityczna „Polityki" nie była tożsama z linią Studnickiego, jednak zdecydowanie wpisywała się w nurt, którego autor Sprawy Polskiej był niewątpliwie inicjatorem.

Giedroyc w Autobiografii na cztery ręce wspomniał:

Zatwierdzenie artykułów do druku należało, rzecz jasna do mnie.

Niekiedy radziłem się kogoś innego, zależnie od tematu artykułu. Kilkakrotnie odbyły się np. dyskusje z Adziem Bocheńskim na tematy niemieckie, gdyż on w pewnych spawach szedł za daleko, był pod zbyt wielkim wpływem Studnickiego. Na ten temat były między nami spory. Adzio opowiadał się za ścisłą współpracą Polski z Niemcami, ja podzielałem zaś pogląd Swianiewicza, który ckim, $50 \mathrm{k}$. 
uważał, że współpraca jest konieczna, ale uważał też, że nie powinna iść za daleko ${ }^{27}$.

Trudno obecnie rozstrzygać kwestie dyskusji programowych w redakcji „Buntu", należy podkreślić, że różnice pomiędzy Bocheńskim a Studnickim były zasadnicze, natomiast zakładane spory pomiędzy Bocheńskim a Giedoroyciem dotyczyły raczej akcentów niż spraw zasadniczych, skoro Bocheński kształtował, prawdopodobnie nie bez ingerencji redaktora, program środowiska. Jednak nie należy zapominać, że jeżeli wskazujemy Studnickiego jako inspiratora Bocheńskiego, to trzeba rozszerzyć na środowisko „Buntu", w dużej mierze z Giedroyciem na czele. Stąd wspomnienie Studnickiego w "Kulturze" posiadało również ten, niezbyt akcentowany wymiar, intelektualnej historii Jerzego Giedroycia.

Maszynopis poniżej przywołanego tekstu znajduje się w zbiorach archiwum Instytutu Literackiego Kultura w Maison-Laffitte. Tekst opatrzono aparatem naukowym, starano zachować się specyfikę stylistyczną, poprawiając jedynie ważniejsze niejasności stylistyczne. 


\section{Bibliografia}

Źródła archiwalne

Archiwum Instytutu Literackiego Kultura, Kor Red Swianiewicz

Archiwum Instytutu Literackiego Kultura, TR „K" nr spec. niemiecki 1984/13, S. Swianiewicz, Wspomnienie o Studnickim.

\section{Opracowania}

Eberhardt P., Geneza niemieckiej koncepcji "Mitteleuropy", „Przegląd Geograficzny", t. 77 (2005), 463-483.

Giedroyc J., Autobiografia na cztery ręce, red. K. Pomian, Warszawa 1994

Gzella J., Zaborcy i sassiedzi Polski w myśli społeczno-politycznej Władysława Studnickiego (do 1939 roku), Toruń 1998.

Lipski J. J., Pisma polityczne. Wybór, Warszawa 2011.

Łoś S., "Świat się w mych oczach dwukrotnie zawalit..." Wspomnienia dyplomaty, red. M. Marszał, S. Wójtowicz, Kraków-Warszawa 2017.

Sadkiewicz J., "Ci, którzy przekonać nie umieja". Idea porozumienia polsko-niemieckiego w publicystyce Władysława Studnickiego $i$ wileńskiego "Słowa" (do 1939), Kraków 2012.

Stempin A., Generał-pułkownik Hans Hartwig von Beseler - generalny gubernator warszawski w latach 1915-1918, "Dzieje Najnowsze" R. 43, z. 3 (2011).

Studnicki W., Sprawa Polska, Poznań 1910.

Studnicki W., W sprawie obchodu grunwaldzkiego, Kraków 1910. 


\section{Abstrakt}

Maciej Zakrzewski

Stanisław Swianiewicz i jego wspomnienie o Studnickim [nota redakcyjna]

Jesienią 1984 r. Jerzy Giedoryc wydał niemieckojęzyczny numer „Kultury". Zawierał on artykuły polskich autorów takich jak m.in.: Konstanty Jeleński, Adam Michnik, Zdzisław Najder, Jan Józef Lipski, Jerzy Stempowski, Czesław Miłosz, Gustaw Herling-Grudziński oraz Stanisław Swianiewicz. Zestaw znanych nazwisk silnie podkreślał chęć przedstawienia czytelnikowi niemieckojęzycznemu najwybitniejszych autorów mniej lub bardziej związanych z Instytutem Literackim. Prezentowane teksty nie tylko traktowały o zagadnieniu relacji polsko-niemieckich, ale też były swoistą promocją tego, czym jest „Kultura" w kręgu niemieckim. Jeden z tekstów autorstwa Swianiewicza był poświęcony postaci Władysława Studnickiego - najważniejszego przedstawiciela orientacji proniemieckiej w latach I wojny światowej i II Rzeczpospolitej. Tekst nigdy nie wyszedł w języku polskim. Dzięki życzliwości Instytutu Literackiego w Masoin-Laffite na łamach pisma "Folia Historica Cracoviensa" ukazuje się polski pierwowzór opublikowanego niemieckiego tłumaczenia. A jest to tekst wyjątkowy. Swianiewicz nie tylko znakomicie przedstawia najważniejsze elementy doktryny Studnickiego, nie tylko wnikliwie przedstawia społeczne tło jego poglądów, ale przytacza szereg osobistych wspomnień odnośnie do tej postaci. Dzięki Swianiewiczowi nie tylko poznajemy koncepcje czołowego polskiego "germanofila", ale przede wszystkim odczujemy ją poprzez wnikliwą i miejscami zaskakującą interpretację autora.

\section{Słowa kluczowe:} Władysław Studnicki, Stanisław Swianiewicz, Jerzy Giedroyc, Kultura, III Rzesza, polityka zagraniczna Polski, orientacja proniemiecka 


\section{Abstract}

Maciej Zakrzewski

Stanisław Swianiewicz's reminiscence about Władysław Studnicki (compiled by M. Zakrzewski)

\section{Keywords:}

Władysław

Studnicki,

Stanisław

Swianiewicz,

Jerzy Giedroyc,

Kultura, Third

Reich, Poland's

foreign policy, pro-

German faction
In autumn 1984 Jerzy Giedroyc published a German issue of Kultura. It contained articles by Polish authors such as Konstanty Jeleński, Adam Michnik, Zdzisław Najder, Jan Józef Lipski, Jerzy Stempowski, Czesław Miłosz, Gustaw Herling-Grudziński and Stanisław Swianiewicz. This list of renowned names emphasized the wish to familiarize the German reader with the greatest writers closely or loosely connected with the Literary Institute. The issue contained texts not only on the Polish-German relations, but was also a genuine attempt at promoting Kultura in German circles. An article by Swaniewicz was dedicated to the life of Władysław Studnicki - the most important representative of the pro-German faction during War World I and the Second Polish Republic. The article has never been published in the Polish language. Courtesy of the Literary Institute in Masoins-Laffitte, Folia Historica Cracoviensa presents the original Polish work which was later translated into German. It is a very special text. Not only does Swaniewicz perfectly outline the key tenets of Studnicki's doctrine and detail the social backdrop of Studnicki's opinions, but he also revisits a number of personal memories of this figure. Thanks to Swaniewicz, in addition to studying the concept of the leading Polish 'Germanophile', we may also sense it through the author's insightful and, at times, surprising interpretation. 